\title{
Implementasi Media Laboratorium Virtual Pada Pendekatan Kooperatif Terhadap Peningkatan Kreativitas Fisika Mahasiswa STMIK Handayani Makassar
}

\author{
Ulfa Laela Rambega \\ STMIK Handayani Makassar \\ ulfalaela@rocketmail.com
}

\begin{abstract}
ABSTRAK
Pembelajaran dengan media laboratorium virtual merupakan media yang yang membuat mahasiswa terlibat aktif dalam proses pembelajaran serta melakukan proses perilaku kreatif. Penelitian ini adalah penelitian eksperimen sesungguhnya yang bertujuan untuk mengetahui perkembangan tingkat kreativitas mahasiswa setelah diterapkan media pembelajaran laboratorium virtual pada pendekatan kooperatif.Populasi pada penelitian ini adalah mahasiswa STMIK Handayani Makassar yang terdiri 2 kelas dan sampel dalam penelitian ini sebanyak 61 mahasiswa. Kelas eksperimen I diberi perlakuan dengan menggunakan media laboratorium virtual dan kelas eksperimen 2 diberi perlakuan menggunakan media laboratorium nyata. Adapun nilai hasil rata-rata kelas eksperimen I sebesar 72,00 dan persentase nilai angket tingkat kreativitas pada kriteria sangat kreatif diperoleh 32\% dan kelas eksperimen II diperoleh 67,00 dengan persentase nilai angket tingkat kreativitas pada kriteria sangat kreatif sebesar $7 \%$.Berdasarkan hasil tersebut dapat disimpulkan bahwa pembelajaran dengan menggunakan media laboratorium virtual dapat mengembangkan kemampuan berpikir kreatif mahasiswa.
\end{abstract}

Kata Kunci: Media laboratorium virtual, kemampuan berpikir kreatif

\section{PENDAHULUAN}

Salah satu permasalahan penting dalam proses pembelajaran adalah rendahnya kualitas pembelajaran terhadap mahasiswa. Kualitas proses dan hasil belajar fisika ditentukan oleh banyak faktor, salah satunya ketersediaan sarana laboratorium. Kerja laboratorium merupakan hal yang penting dilaksanakan dalam pembelajaran fisika, karena melalui kerja laboratorium aspek produk, proses, dan sikap mahasiswa dapat lebih dikembangkan. Pembelajara fisika melalui media laboratorium dapat meningkatkan efisiensi, motivasi, serta menfasilitasi belajar aktif, belajar eksperimental, konsisten dengan belajar yang berpusat pada peserta didik, dan sangat potensial untuk meningkatkan kreativitas peserta didik (Malik,2010)

Pelaksanaan praktikum dalam fisika sangat penting dalam rangka mendukung pembelajaran dan memberikan penekanan pada aspek proses.hal ini diasarkan pada tujuan pembelajaran fisika sebagai proses yaitu meningkatkan kemampuan berpikir mahasiswa.
Praktik laboratorium adalah salah satu cara yang ditempuh untuk mencapai tujuan ini. Praktikum fisika memberikan kesempatan alami kepada siswa untuk belajar melakukan suatu percobaan dan menganalisa data yang diperoleh sesuai dengan tujuan percobaan yang dilakukan.(Purnomo:2011)

Laboratorium virtual merupakan suatu media berbasis komputer yang berisi simulasi kegiatan di laboratorium fisika. Laboratorium virtual dibuat untuk menggambarkan reaksi-reaksi yang mungkin tidak dapat terlihat pada keadaan nyata (Totiana:2011)

Virtual laboratory didefenisikan sebagai suatu objek multimedia intraktif. Objek multimedia interaktif terdiri dari bermacam format heterogen termasuk teks, hiperteks, suara, gambar, animasi, video, dan grafik . ( Gunawan:2011)

Sementara itu, vygotsky mengemukakan bahwa seoran peserta didik yang memiliki kemampuan yang rendah akan dapat mengembangkan tingkat pemahaman dan keterampilan mereka lebih tinggi melalui proses 
kolaborasi dan kerjasama dengan rekan sebaya mereka yang memiliki tingkat kemampuanyang lebih baik. Teori ini diaplikasikan pada metode pembelajaran kooperatif.

Alasan mengapa kreativitas dijadikan sebagai salah satu objek masalah dalam hubungannya dengan prose pembelajaran dalam penelitian ini karena berawal dari hasil belajar yang tidak seimbang dan pelaksanaan proses pembelajaran yang kurang mampu mengeksploitasi kreativitas mahasiswa dalam hubungannya dengan ranah konitif,padahal aspek ini sangat membantu mahasiswa apalagi melalui media laboratorium virtual sehingga mereka bias melahirkan kemampuan berpikir, bergerak dan kepribadian yang baik melalui kreativitas. Tapi hal ini tidak didapatkan oleh mereka sebagai konsumen dalam mempelajari fisika.

Kurangnya kreativitas mahasiswa juga disebabka oleh rangkaian pelaksanaan pembelajran yang bersifat konvensional, menggunakan cara-cara lama dan sedikit membosankan mahasiswa. Mengingat pentingnya peran kreativitas bagi mahasiswa, kreativitas diharapkan dapat berkembang secara maksimal dalam hal ini merupakan proes berpikir dimana mahasiswa berusaha utuk menemukan hubugan-hubungan baru, mendapatkan jawaban, metode atau cara memecahkan suatu masalah. (Menurut Filsaime dalam Fauziah: 2011), berpikir kreatif adalah proses berpikir yang memiliki ciri-ciri kelancaran (fluency), keluwesan (flexibility), keaslian atau originalitas (originality) dan merinci atau elaborasi (elaboration).

Berdasarkan hasil analisis dan identifikasi masalah mahasiswa STMIK Handayani Makassar dianggap kurang memiliki kemampuan berpikir kreatif, dengan alasan bahwa mereka hanya mampu memahami fisika terutama yang berkaitan dengan praktikum dan hanya memengaruhi hasil belajar ranah kognitif yang tidak seimbang .jika peralatan laboratorium tidak memadai maka salah satu solusinya adalah memanfaatkan media pembelajaran berupa laboratorium virtual. Setiawan (2009) menyatakan bahwa peserta didik yang belajar menggunakan virtual laboratory memiliki kemampuan interfensi logika yang lebih baik dibangdingkan peserta didik yang belajar secara konvensional.

Berawal dari pemikiran diatas, Peneliti menjelaskan konsep fisika yang bersifat abstrak dengan menggunakan media laboratorium virtual pada materi dualism gelombang sebagai solusi terbatasnya fasilitas laboratorium. Sehingga peneliti mengambil judul ‘ Implementasi media laboratorium virtual pada pendekatan kooperatif terhadap peningkatan kreativitas fisika mahasiswa STMIK Handayani Makassar.

\section{METODE PENELITIAN}

Jenis penelitian yang digunakan dalam penelitian ini adalah jenis penelitian Post test only group design dimodifikasi melalui pengacakan dengan asumsi kelas yang diacak adalah kelas homogen.

Dalam penelitian ini varabel yang dilibatkan pada penelitian ini secara operasional. 1) Pembelajaran kooperatif adalah kegiatan yang dilakukan dengan mengelompokkan 4-5 orang mahasiswa dalam bekerjasama tugas yang diberikan. 2) Pembelajaran media laboratorium virtual adalah sebuah media yang berbasis komputer yang memungkinkan mahasiswa dapat melakukan praktikum atau eksperimen seolah menghadapi fenomena atau set peralatan laboratorium nyata. dan 3) Pembelajaran tanpa media laboratorium virtual adalah pelajaran yang diberikan dengan menggunakan alat-alat praktikum nyata. Adapun indicator dalam penelitian ini yakni oleh (Munandar,2012) sebagai berikut: a) Berpikir Lancar, b) Berpikir Luwes, c) Berpikir Orisinil ,dan d) Berpikir Terperinci.

\section{Teknik Analisis Data}

Teknik analisis data yang digunakan untuk menganalisis data tingkat kreativitas mahasiswa terhadap pembelajaran fisika pada pendekatan kooperatif dengan menggunakan pola skala likert. Hasil tes peningkatan kreativitas dan angket tingkat kreativitas dinalisis dengan rumus:

$n \quad=\frac{n}{N} \times 100 \%$ (Arikunto, 2006:281) 
Mengkoversikan persentase kedalam bentuk kualitatif.menentukan persentase skor maksimal:

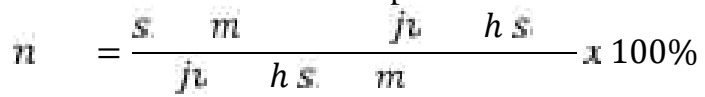

Menentukan persentase skor minimal:

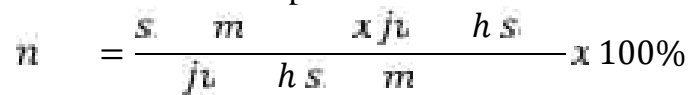

Menentukan range persentase skor

Range $=$ \%perolehan maksimal-\%perolehan minimal

range $=100 \%-25 \%=75 \%$

Menentukan Lebar interval

$$
\begin{array}{llll}
\text { lt } & \text { it } & =\frac{r}{j u} h k & h k \\
\text { lt } & \text { in } & \frac{75 \%}{4}=18,75 \%
\end{array}
$$

Menentukan deskripsi kualitatif untuk setiap interval:

$25 \% \leq \mathrm{p} \leq 43,75 \%=$ kurang

kreatif, $43,75 \% \leq \mathrm{p} \leq 62,5 \%=$ cukup kreatif, $62,5 \% \leq \mathrm{p} \leq$ $81,25=$ kreatif $, 81,25 \% \leq \mathrm{p} \leq 100 \%=$ sangat kreatif

\section{HASIL PENELITIAN}

Dari hasil post-test kelas eksperimen I dan eksperimen II selengkapkapnya dapat dilihat pada tabel 1 sebagai berikut:

Tabel 1. Hasil post-test

\begin{tabular}{clcc}
\multirow{2}{*}{ No } & \multirow{2}{*}{ Komponen } & \multicolumn{2}{c}{ kelas } \\
\cline { 3 - 4 } & & Eksp I & Eksp II \\
\hline 1 & Mahyaknya & 31 & 30 \\
2 & Nilai Rata-rata & 72 & 67 \\
3 & Nilai Tertinggi & 85 & 78 \\
4 & Nilai Terendah & 60 & 55 \\
\hline Berdasarkan tabel & diatas & menunjukkan
\end{tabular}
adanya pengaruh atau perkembangan yang baik. Kedua kelas mengalami perbedaan dengan nilai rata-rata kelas eksperimen I lebih tinggi daripada nilai kelas eksperimen II.

Hasil dari tingkat kreativitas kelas eksperimen I dan eksperimen II selengkapkapnya dapat dilihat pada tabel 2 sebagai berikut:

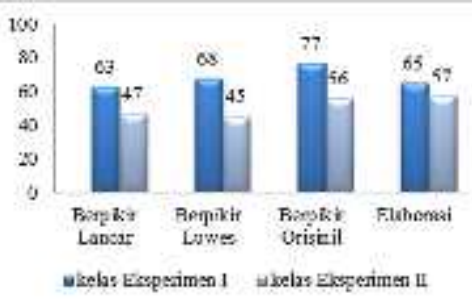

Gambar 1. Hasil Indikator Tingkat kreativitas
Pada gambar di atas menunjukkan indikator kelas eksperimen I mengalami kenaikan yang cukup signifikan di bandinkan kelas eksperimen II .

Hasil Analisis deskriptif angket mahasiswa menggunakan angket respon yang berisi pernyataan-pernyataan yang mengacu pada indikator kemampuan berpikir kreatif secara kognitif. Hasil analisis dskriptif persentase klasikal tingkat kreativitas mahasiswa dapat diliahap pada gambar 2 dibawah ini:

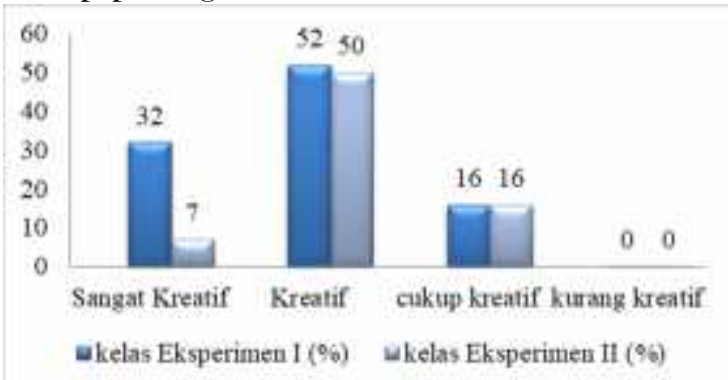

Gambar 2. Hasil deskripsi kualitatif untuk setiap interval

Hasil angket tanggapan mahasiswa menyatakan bahwa dengan media laboratorium virtual dapat mengembangkan kemampuan tingkat kreativitas. Berkaitan dengan hasil nilai rata-rata dan ketuntasan klasikal kelas eksperimen I mempunyai nilai lebih baik dari kelas eksperimen II.

\section{PEMBAHASAN}

Berdasarkan hasil pengujian mengenai elaksanaan pembelajaran dikelas diperoleh bahwa metode ceramah, fasilitas berupa laboratorium dan alat-alat praktikum jarang sekali digunakan sehingga untuk mencari solusi yang tepat maka digunaan media laboratorium virtual karena dengan menggunakan media ini dapat memudahkan mahasiswa memahami materi pembelajaran dan memberikan keamanan pada saat praktikum serta mengoptimalkan waktu belajar.

Hasil uraian secara umum diperoleh rata-rata nilai post-test kelas eksperimen I sebesar 72,00 dan kelas eksperimen II sebesar 67,00.Kondisi tersebut menunjukkan bahwa kondisi kedua sampel adalah berbeda. Pada sedangkan hasil analisis pengembangan tingkat kreativitas mahasiswa melalui beberapa indikator seperti 
indikator berpikir lancar menunjukkan tingkat kreativitas pada kelas ekperimen I lebih tinggi dari kelas ekperimen II begitupula pada indikator-indikator lainnya seperti pada indicator berpikir luwes terlihat tingkat kreativitasnya diperoleh 68,00 pada kelas eksperimen I dan kelas eksperimen II diperoleh 45,00. Hal ini menunjukkan penggunaan media ini sangat mendukung mahasiswa dalam kegiatan laboratorium dalam pelaksanaan kegiatan ini mahasiswa dapat belajar sambil berbuat, bekerja sendiri untuk menemukan maupaun untuk membuktikan kebenaran teori dengan tujuan agar kemampuam berpikir kreatif mahasiswa dapat berkembang.

Hasil diatas sejalan dengan hasil penelitian sebelumnya bahwa model virtual laboratory fisika modern dapat meningkatkan keterampilan generik sains calon guru (Salam: 210)

Untuk hasil analisis angket respon mahasiswa pada gambar 2 diperoleh tingkat persentase untuk kelas ekperimen I dengan katagori sangat kreatif sebesar 32\% dan kelas ekperimen II sebesar 7\% hal ini menunjukkan bahwa melalui media ini mahasiswa tidak hanya belajar teori melainkan juga melakukan percobaan untuk memperoleh hasil berupa pengetahuan serta dapat mengaitkan antara materi dengan kehidupan sehari-hari.

Proses pembelajaran ini melalui media interaktif sangat membantu menumbuhkan perilaku kreatif siswa karena selama pelaksanaan pembelajaran ini mahasiswa melaksanakan kegiatan-kegiatan yang merupakan proses perilaku kreatif yaitu persiapan, inkubasi,iluminasi, dan verifikasi. Proses perilaku kreatif tersebut dilakukan oleh mahasiswa sampai penarikan kesimpulan.

Penggunaan laboratorium virtual dapat meningkatkan kemampuan Tingkat Kreativitas mahasiswa. Laboratorium virtual dapat dijadikan alternatif untuk melakukan eksperimen fisika. Selain lebih murah dan terjangkau, juga lebih aman bagi mahasiswa sebagai pengguna. Mahasiswa juga dapat melakukan eksperimen dimanapun dan kapanpun sesuai kebutuhannya.

Terdapat beberapa keuntungan yang diperoleh dari proses belajar mengajar yang telah dilakukan dengan menggunakan laboratorium virtual, antara lain (1) lebih ekonomis karena tidak membutuhkan bangunan lab, alat-alat dan bahan-bahan seperti pada laboratorium konvensional, (2) menambah motivasi dalam proses belajar mengajar, (3) siswa mempunyai keterampilan pemecahan masalah dan kemampuan berpikir tingkat tinggi dalam pembelajaran ataupun dalam permasalahan sehari-hari.(Hermansyah,dkk:2015)

\section{KESIMPULAN}

Berdasarkan hasil penelitian dan pembhasan didapatkan kesimpulan bahwa terjadi pengembangan kemampuan tingkat kreativitas mahasiswa yang menerapakan pembelajaran menggunakan media laboratorium virtual dibandingkan dengan menggunakan media laboratorium nyata. hal tersebut dilihat dari post test serta indikator yang mulai berkembang dalam penelitian ini adalah berpikir lancer, luwes, orisinil dan elaborasi. Sedangkang hasil kemampuan berpikir kreatif mahasiswa didalam penelitian ini juga menyebabkan persentase smahasiswa kreatif sangat klasikal.

\section{DAFTAR PUSTAKA}

Arikunto, S. 2005. Menajemen Penelitian. Jakarta: Rineka cipta

Fauziah. 2011. Analisis Kemampuan Guru Dalam Mengembangkan Keterampilan Berfikir Kreatif Siswa Sekolah Dasar Kelas V Pada Pembelajaran Ilmu Pengetahuan Alam. Edisi Khusus No. 2, Agustus 2011. ISSN 1412-565x.

Gunawan. 2011. Persepsi dosen dan mahasiswa terhadap model virtual laboratory fisika modern. Jurnal kependidikan, vol. 10 no. 2, November 2011. ISSN 1412-6087. Mataram: Lembaga Penelitian Dan Pengembangan Pada Masyarakat IKIP Mataram.

Hermansyah,dkk.2015. Pengaruh Penggunaan Laboratorium Virtual Terhadap Penguasaan Konsep dan Kemampuan Berpikir Kreatif Siswa Pada Materi Getaran dan Gelombang. Jurnal Pendidikan Fisika Vol 1 No 2 tahun 
2015 Progran Studi Pendidikan Fisika

Universitas Mataram .ISSN 2407-6902)

Malik,A. (2010) Model Pembelajaran Inkuiri Menggunakan Virtual Laboratory dan Real Laboratory Untuk Meningkatkan Penguasaan Konsep Dan Keterampilan Berpikir Kritis siswa SMA pada Topik Listrik Dinamis.bandung: UPI

Purnomo, H. 2011. Laboratorium Virtual Sebagai Alternatif Kegiatan Laboratorium Kovensional Di Perguruan Tinggi. Orbith Vol. 7 No. 3 November 2011: 418-421

Salam, H, dkk. 2010. Pembelajaran Berbasis Virtual Laboratory Untuk Meningkatkan Penguasaan Konsep pada Materi Listrik Dinamis. Proceedings of The 4th International Conference on Teacher Education; Join Conference UPI \& UPSI Bandung, Indonesia, 8-10 November 2010.

Setiawan, A. (2009) Pengembangan virtual Laboratory Fisika Modern Berorientasi Keterampilan Generik Sains. Bandung: UPI Totiana, F dkk. 2012. Efektivitas Model Pembelajaran Creative Problem Solving (Cps) Yang Dilengkapi Media Pembelajaran Laboratorium Virtual Terhadap Prestasi Belajar Siswa Pada Materi Pokok Koloid Kelas Xi Ipa Semester Genap Sma Negeri 1 Karanganyar Tahun Pelajaran 2011/2012. Jurnal Pendidikan Kimia (JPK), Vol. 1 No. 1 Tahun 2012 Program Studi Pendidikan Kimia Universitas Sebelas Maret. ISSN 2337-9995. [4] 